\title{
Opening Address: President of ICMI
}

\author{
Bill Barton
}

Honourable Mr Lee, Minister of Education

Professor Sung Je Cho, Convenor of this wonderful conference

ICMI Colleagues and friends

Our moment has arrived. Isn't this wonderful!

I am delighted to be here, to open the 12th International Congress of Mathematics Education - to be honest, it is a moment I have been looking forward to for more than 4 years. Our community is very fortunate to have attracted a conference bid from Korea, and our Korean friends are already proving to us that we made a very good decision to accept their bid.

These few minutes are my opportunity to address the wider ICMI community about the things that I believe are important about mathematics education on the international stage. I cannot detail all the many, many activities of ICMI as an organisation: ICMI Studies, Regional conferences, Affiliated organisations, and on and on. I urge everyone in this room to find out who their ICMI country representative is, and ensure that they become part of their national network. You should also subscribe to the ICMI Newsletter (on line) or become a Facebook Friend. We survive as an organisation through your participation.

I wish to mention three topics: our major development project; the Klein Project; and finally some comments on how our community communicates.

Since the last ICME in Mexico, ICMI as an organisation has changed dramatically. We have extended our development activities significantly. It is no longer true that we are primarily an organisation of professionals in mathematics education. Now we spend at least half our efforts and resources on worldwide development activities. A major part of this effort is the Capacity and Networking Project, that we call CANP.

\footnotetext{
B. Barton $(\bowtie)$

Former President of International Commission on Mathematical Instruction,

University of Auckland, Auckland, New Zealand

(C) The Author(s) 2015

S.J. Cho (ed.), The Proceedings of the 12th International Congress

on Mathematical Education, DOI 10.1007/978-3-319-12688-3_2
} 
The aim of CANP is to support developing regions to form self-sustaining networks of mathematics educators, mathematicians, government officials, and, of course, teachers. What ICMI does is to organise a two-week Workshop in a different region every year. Last year the first was held in Mali, this year the second will be held in Costa Rica, and next year it will be Cambodia. A region of four or five countries is selected, and a Scientific Committee is formed of four people from the international community and four from the region. The Workshop is usually about fifty people representing all the groups in the network. The focus of the Workshop is secondary teacher education, but the aim is really to get key people in the region working together. Funds for each CANP programme are raised separately, we have had significant support from IMU, UNESCO, CIMPA and other organisations.

My second topic is the Klein Project. I invite everyone to turn ON their smartphones or open their computers - please go to the Klein Project Blog <http:// blog.kleinproject.org $>\ldots$ or at least write this down, and $\log$ in at your first opportunity. The Klein Project is a worldwide project to produce writing on contemporary mathematics for secondary school teachers. Note: it is not designed for use in classrooms, but for the pleasure and satisfaction of teachers. In the Klein Blog you will find Klein Vignettes - these are short (4-6 pages) on a contemporary topic, written for secondary school mathematics teachers.

Over the next months you will see the Klein Blog grow-both with new Vignettes, but also as we translate the Vignettes into any and every language. This is a major task for our community, and I seek your help to offer to translate the Vignettes into your languages.

Eventually there will also be a Klein Project book - a small volume aimed at secondary teachers, that they will be able to dip into in the spare moments of their busy teaching lives. A book that will sustain and inspire teachers mathematically.

Please will you have a look, feed back to the project with your reactions, offer to help write more materials, and, most importantly, spread the Blog address amongst your secondary teacher friends and networks - or anyone whom you think would be interested.

I mention the Klein Project not because it is ICMI's only project-it is not, we have several others-but because it illustrates for me an very important point: that ICMI works more closely than ever with IMU, the world body of mathematicians. The Klein Project is a joint project with IMU, and every piece of writing is the result of collaborations between mathematics teachers, educators, and mathematicians.

And lest you think that ICMI is focused only on secondary teachers and mathematicians, let me quickly say: "Look out for the next ICMI Study announcement - it will be on Primary Mathematics". Watch for the announcement in December.

Finally, allow me to note that ICMI is changing in another respect-it is changing in the way the world is changing. New technologies, new modes of communication, new groupings, new social imperatives, new problems to be solved and questions to be answered. ICMI must and does change, and in particular we 
change in the way we communicate. We have a Facebook page, we have a bank of digitised publications, we have an ever increasing website. In what new ways will we meet and communicate in four years time? We need the new members of our community to lead us in this matter-and I call on you all to embrace the movement forward into new worlds.

But face-to-face communication will, in my opinion, always be highly valued. Being able to Skype my grandchildren or my research colleagues on the other side of the world only makes me want to actually see them and spend time with them so much more.

And this is why we are here. To greet and see and talk to each other. To make new friends and affirm old ones. And we do this with great pleasure at the same time as we work hard to improve the learning of mathematics in classrooms at all levels in every country.

Thus I regard it as one of the greatest honours of my career to declare the 12th International Congress on Mathematics Education Officially open.

Open Access This chapter is distributed under the terms of the Creative Commons Attribution Noncommercial License, which permits any noncommercial use, distribution, and reproduction in any medium, provided the original author(s) and source are credited. 